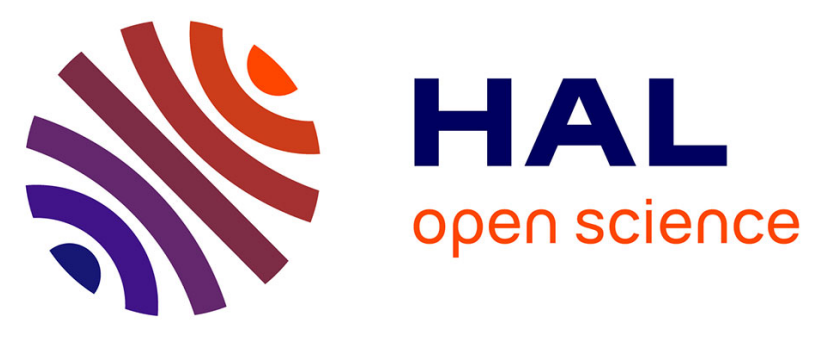

\title{
Differentiation between fresh and frozen-thawed sea bass (Dicentrarchus labrax) fillets using two-dimensional gel electrophoresis
}

Pierrette Ethuin, Sylvain Marlard, Mylène Delosière, Christine Carapito, Francois Delalande, Alain van Dorsselaer, Alexandre Dehaut, Valérie Lencel, Guillaume Duflos, Thierry Grard

\section{To cite this version:}

Pierrette Ethuin, Sylvain Marlard, Mylène Delosière, Christine Carapito, Francois Delalande, et al.. Differentiation between fresh and frozen-thawed sea bass (Dicentrarchus labrax) fillets using two-dimensional gel electrophoresis. Food Chemistry, 2015, 176, pp.294-301. 10.1016/j.foodchem.2014.12.065 . anses-02567066

\section{HAL Id: anses-02567066}

https://hal-anses.archives-ouvertes.fr/anses-02567066

Submitted on 14 May 2020

HAL is a multi-disciplinary open access archive for the deposit and dissemination of scientific research documents, whether they are published or not. The documents may come from teaching and research institutions in France or abroad, or from public or private research centers.
L'archive ouverte pluridisciplinaire HAL, est destinée au dépôt et à la diffusion de documents scientifiques de niveau recherche, publiés ou non, émanant des établissements d'enseignement et de recherche français ou étrangers, des laboratoires publics ou privés. 
1 Differentiation between fresh and frozen-thawed sea bass (Dicentrarchus labrax) fillets

2 using two-dimensional gel electrophoresis

3 Short title: Use of 2D-electrophoresis to differentiate fresh from thawed sea bass fillets

4 Pierrette Ethuin ${ }^{\mathrm{a}^{*}}$, Sylvain Marlard ${ }^{\mathrm{a}}$, Mylène Delosière ${ }^{\mathrm{b}}$, Christine Carapito $^{\mathrm{c}}$, François

5 Delalande $^{\mathrm{c}}$, Alain Van Dorsselaer ${ }^{\mathrm{c}}$, Alexandre Dehaut ${ }^{\mathrm{d}}$, Valérie Lencel ${ }^{\mathrm{a}}$, Guillaume Duflos ${ }^{\mathrm{d}}$

6 and Thierry Grard

$7 \quad{ }^{a}$ Université du Littoral Côte d'Opale, équipe Biochimie des Produits Aquatiques (BPA), Boulevard du Bassin

$8 \quad$ Napoléon, BP 120, 62327 Boulogne-sur-Mer, France

9 b INRA, UR 370 Qualité des Produits Animaux (QuaPA), Site de Theix, 63122 Saint-Genès-Champanelle,

10 France

$11{ }^{\mathrm{c}}$ Laboratoire de Spectrométrie de Masse BioOrganique (LSMBO), IPHC, Université de Strasbourg, CNRS

12 UMR7178, Strasbourg, France

$13{ }^{\mathrm{d}}$ ANSES, Laboratoire de Sécurité des Aliments - Département des Produits de la Pêche et de l'Aquaculture,

14 Boulevard du Bassin Napoléon, 62200 Boulogne-sur-Mer, France

$15{ }^{*}$ Corresponding author: Tel: +33 3219945 20; Fax: +33 321994524.

16 E-mail address: pierrette.ethuin@univ-littoral.fr (P. Ethuin). 


\section{Abstract}

This study aimed to identify a protein marker that can differentiate between fresh skinless and frozen-thawed sea bass (Dicentrarchus labrax) fillets using the two-dimensional polyacrylamide gel electrophoresis (2-DE) technique. Distinct gel patterns, due to proteins with low molecular weight and low isoelectric points, distinguished fresh fillets from frozenthawed ones. Frozen-thawed fillets showed two specific protein spots as early from the first day of the study. However, these spots were not observed in fresh fillets until at least 13 days of storage between 0 and $4^{\circ} \mathrm{C}$, fillets were judged, beyond this period, unfit for human consumption as revealed by complementary studies on fish spoilage indicators: total volatile basic nitrogen and biogenic amines. Mass spectrometry identified the specific proteins as parvalbumin isoforms. Parvalbumins may thus be useful as markers of differentiation between fresh and frozen-thawed sea bass fillets.

Keywords: Sea bass (Dicentrarchus labrax), 2D-electrophoresis, frozen-thawed, fresh, biogenic amines

\section{Chemical compounds studied in this article:}

3-[(3-Cholamidopropyl)dimethylammonium]-1-propanesulfonate (PubChem CID 107670); Acetonitrile (PubChem CID 6342); Diaminopropane (PubChem CID 6567); Dithiothreitol (PubChem CID 19001); Ethanol (PubChem CID 702); Formic acid (PubChem CID 284); Iodoacetamide (PubChem CID 3727); Perchloric acid (PubChem CID 24247); Tris(hydroxymethyl)aminomethane hydrochloride (PubChem CID 93573); Urea (PubChem CID 1176) 


\section{Introduction}

Over the past several years, wild-caught fish have become rare although consumer demand for them has increased. The development of frozen storage has allowed producers and suppliers to commercialize products worldwide, and thus meet consumer demand. Nevertheless, a common practice consists in thawing frozen fish and selling it as fresh fish; this practice is illegal under current regulations in the European Union, as mentioned in Directive 2000/13/EC, which lays down the rules for the labelling of foodstuffs including specifications as to their physical condition and the specific treatment that they have undergone (e.g. deep-frozen). There are several methods to differentiate between fresh and frozen-thawed fish (Duflos, Le Fur, Mulak, Becel, \& Malle, 2002; Karoui, Thomas, \& Dufour, 2006). Some methods are suitable for whole fish and skin-on fillets, but difficulties remain in distinguishing fresh from frozen-thawed skinless fillets. Currently, no accurate, sensitive, rapid and inexpensive method is available for producers, suppliers and official authorities to determine directly if a skinless fish fillet has been frozen. Freezing and thawing causes sensory changes and quality decay (Matsumoto, 1979; Tironi, De Lamballerie, \& LeBail, 2010; Tironi, LeBail, \& De Lamballerie, 2007), increases protein denaturation (Benjakul \& Bauer, 2001), lipid oxidation (Baron, Kjaersgard, Jessen, \& Jacobsen, 2007; Duun \& Rustad, 2007) and drip loss (Zhu, Ramaswamy, \& Simpson, 2004). For moderate subfreezing temperatures, extracellular water usually freezes and cells may suffer from severe osmotic contraction. During freezing, the formation of large ice crystals leads to high mechanical damage in cells (Martino, Otero, Sanz, \& Zaritzky, 1998; Tironi, LeBail, \& De Lamballerie, 2007), affecting their membranes and other ultrastructural elements (Mazur, 2010; Pegg, 2010) and causing them to release intracellular protein exudates. Furthermore, during thawing, the diluted external medium causes an increase in cell volume, and the plasma membrane cannot withstand such high hydrostatic pressure (Tchir \& Acker, 2010). 
66

67

To differentiate fresh from frozen-thawed fish, proteomics was used - a technique applied for analyzes such as species identification (Berrini, Tepedino, Borromeo, \& Secchi, 2006; Etienne et al., 2001), tissue and development stage identification (Martinez \& Friis, 2004), and more specifically, for documentation of changes in cod muscle during frozen storage (Kjaersgard, Norrelykke, \& Jessen, 2006) or differentiation between wild and farmed cod (Martinez, Slizyte, \& Dauksas, 2007). Regarding sea bass, studies have used 2Delectrophoresis to evaluate freshness (Verrez-Bagnis, Ladrat, Morzel, Noël, \& Fleurence, 2001) or to provide detailed characterization of its specific protein expression profile (Terova, Pisanu, Roggio, Preziosa, Saroglia, \& Addis, 2014).

Here, farmed sea bass (Dicentrarchus labrax) was chosen as a model because it has several advantages: low genetic variation, identical feed, environmental conditions and temperature, same age pyramid, graded weight, and known date of death.

The protein composition of the sea bass fillet exudates was tested after freezing-thawing to assess whether changes are recorded. To avoid selecting potential, non-specific post-mortem markers that are also found in fresh fillet exudates, spoilage indicators were monitored over a period of 15 days. Biogenic amines (BAs) and total volatile basic nitrogen (TVB-N) in fish are quality indices used for food safety assessment. Among the most important BAs, putrescine, cadaverine and histamine are known for their significant negative impact on fish freshness and human health. The purpose of this study was to compare electrophoresis profiles of fresh versus frozen-thawed fillets, to detect spots of interest and to characterize them using mass spectrometry, so as to identify protein markers and determine the fresh or frozen status of stored fillets. 


\section{Materials and methods}

\subsection{Fish material}

Sampled fish came from the Aquanord sea farm (Gravelines, France). Sea bass (D. labrax) were raised in tanks containing 25,000 sea bass at a maximum concentration of $40 \mathrm{~kg}$ per cubic meter. The tanks were connected to a seawater recirculation system with the following strictly controlled conditions: temperature $18 \pm 5^{\circ} \mathrm{C}, \mathrm{pH} 8.2$, total ammonia $<30 \mu \mathrm{mol} / \mathrm{L}$, and dissolved oxygen level over 99\% (v/v) saturation (7 ppm). On day 0, 8 to 10 fish (average body weight $500 \pm 150 \mathrm{~g}$ ) were removed from the water and slaughtered via asphyxia/hypothermia (immersion in ice-cold water at a 3:1 fish-to-ice ratio). The fish were then packed in ice and transported ( $1 \mathrm{~h}$ trip) from Gravelines to Boulogne-sur-Mer (France). The fish were immediately processed (CFPMT, Boulogne-sur-Mer) to obtain skinless fillets. Cling-film protected fillets were stored in polystyrene boxes with crushed ice and kept in cold storage, between 0 and $+2^{\circ} \mathrm{C}$. All stages of the processing, storage and freezing treatments were performed under conditions typical of a fish-processing plant.

Fillets were examined over 15 days, stored between 0 and $+4^{\circ} \mathrm{C}$. Each sampling day (day 0,3 , 6, 9, 13 and 15 after slaughter), fillets were divided into two groups. The first one is composed of a fresh fillets group for immediate analysis: 2-DE profiles and spoilage indicators. During storage of the fresh fillets, water was drained off through drainage holes in the boxes and fresh ice was provided every day. The second one is composed of a frozenthawed fillets group: the fillets were frozen at $-30^{\circ} \mathrm{C}$ at the Plateforme Nouvelles Vagues processing plant (Boulogne-sur-Mer, France) and stored at $-20^{\circ} \mathrm{C}$ for less than 15 days. Afterward, the frozen fillets were removed from the freezer and stored for $24 \mathrm{~h}$ between 0 and $+4^{\circ} \mathrm{C}$ to thaw completely and the same analyses as those for the fresh fillets groups were carried out. 


\subsection{Fish exudate preparation and protein extraction}

Exudates are extracts from flesh juice (Morel, 1979) obtained after centrifugation (Ayala et al., 2005; Duflos, Le Fur, Mulak, Becel, \& Malle, 2002; Tironi, De Lamballerie, \& Le-Bail, 2010). Briefly, sampling for both groups of fish involved taking a piece of white muscle tissue $\left(1 \mathrm{~cm}^{3}\right)$ from the lateral-dorsal (epiaxial) muscle quadrant of each fish. Only the dorsal white flesh of the fillets was used in this study. The preparation of fish exudates was based on soft solubilization of proteins (Duflos, Le Fur, Mulak, Becel, \& Malle, 2002). Each stage of the protocol was performed at $+4^{\circ} \mathrm{C}$. Soluble proteins were obtained from $20 \mathrm{~g}$ of diced white flesh (cubes of approximately $1 \mathrm{~cm}$ on each side) of fresh or frozen-thawed fillets placed in one volume (w/v) of phosphate buffer $(10 \mathrm{mM}, \mathrm{pH} 7.4)$ containing anti-proteases: $1 \%$ phenylmethylsulphonyl fluoride (PMSF) $(10 \mathrm{mg} / \mathrm{mL}$ isopropanol), $0.2 \%$ pepstatin $(0.35$ $\mathrm{mg} / \mathrm{mL}$ ethanol) and $0.1 \%$ leupeptin-aprotinin (combination of leupeptin $0.5 \mathrm{mg} / \mathrm{mL}$ and aprotinin $1 \mathrm{mg} / \mathrm{mL}$ ). After gentle stirring, suspensions were centrifuged at 34,000 $\times \mathrm{g}$, for 30 min at $+4^{\circ} \mathrm{C}$ to obtain exudates. Lipids were discarded by pipetting and the supernatant was filtered twice on a $0.45 \mu \mathrm{m}$ membrane (Millipore, Guyancourt, France). The amount of proteins was determined using the Bradford method (Bradford, 1976) with the Bio-Rad reagent (Bio-Rad, Marnes-la-Coquette, France) and bovine serum albumin (BSA) as standards. Proteins were concentrated on a $10 \mathrm{kDa}$ filter in an Amicon cell 8003 (Millipore). Rehydration buffer containing $8 \mathrm{M}$ urea, 4\% 3-[(3-cholamidopropyl)dimethylammonium]-1propanesulfonate (CHAPS), $20 \mathrm{mM}$ dithiothreitol (DTT), 0.2\% ampholytes (100X Biolyte 310 Ampholyte, Bio-Rad) was added to reach $6.66 \mathrm{mg} / \mathrm{mL}$.

\subsection{Two dimensional gel electrophoresis}

Each solution was filtered on a $0.45 \mu \mathrm{m}$ filter and prepared with ultrapure water (18 M $\Omega$ ) and all products met the quality requirements for proteomics and genomics. 


\subsubsection{Staining}

158 After migration, gels were stained with a silver nitrate staining kit (Sigma-Aldrich, Saint

\subsubsection{First dimension isoelectric electrophoresis focusing (IEF)}

Isoelectric electrophoresis focusing (IEF) was performed according to Hochstrasser, Patchornik, and Merril (1988) with ReadyStrip immobilized pH gradient (IPG) Strips (Bio$\mathrm{Rad}), 17 \mathrm{~cm}$ in length ( $\mathrm{pH}$ gradient $=3-10)$. According to the manufacturer's instructions, the IPG strips were rehydrated for $6 \mathrm{~h}$ (passive rehydration) in a mixture of $300 \mu \mathrm{L}$ of the protein sample and $200 \mu \mathrm{L}$ of rehydration buffer with $0.001 \%$ bromophenol blue used to track migration. Then, $2 \mathrm{mg}$ of protein was loaded in a volume of $500 \mu \mathrm{L}$ on each strip. The rehydrated strips were then positioned in the Protean IEF Cell (Bio-Rad) on the focusing plate for $15 \mathrm{~h}$ at $50 \mathrm{~V}$ (active rehydration). Proteins were focused for $27 \mathrm{~h}$ for a total of $85,000 \mathrm{Vh}$ without exceeding an intensity of $50 \mu \mathrm{A}$ per strip.

After focusing, all strips were incubated in two equilibration buffers for $10 \mathrm{~min}$. The first equilibration buffer contained $6 \mathrm{M}$ urea, 2\% sodium dodecyl sulphate (SDS), $125 \mathrm{mM}$ Tris(hydroxymethyl)aminomethane hydrochloride (Tris-HCl) (pH 7.5) and $50 \mathrm{mM}$ DTT. The second equilibration buffer had the same composition except $150 \mathrm{mM}$ iodoacetamide was used instead of DTT.

\subsubsection{Second dimension electrophoresis}

Equilibrated strips were loaded on $12.5 \%$ SDS gels $(19.5 \times 19.5 \times 0.05 \mathrm{~cm})$ and underwent SDS-polyacrylamide gel electrophoresis. The second dimension was performed as described in Hochstrasser, Harrington, Hochstrasser, Miller, and Merril (1988). Electrophoresis was carried out without exceeding $30 \mathrm{~mA}$ per gel and with a voltage increasing gradually to 350 V. Quentin Fallavier, France). The gels were scanned with GS-800"M Calibrated Densitometer 
160 and PD Quest software (Bio-Rad) The spots of interest were excised and destained with the

161 destaining solution (Sigma-Aldrich) containing $1 \%$ potassium hexacyanoferrate III

$162\left(\mathrm{C}_{6} \mathrm{FeK}_{3} \mathrm{~N}_{6}, 3 \quad \mathrm{H}_{2} 0\right)$ and $1.6 \%$ sodium thiosulphate. The gels were dried between two

163 cellophane membranes and archived.

\subsection{Mass spectrometry analysis}

\subsubsection{Sample preparation and mass spectrometry analysis}

In situ digestion of the gel spots was performed with an automated protein digestion system,

MassPREP Station (Waters, Milford MA, USA) as previously described (Buhr, Carapito, Schaeffer, Hovasse, Van Dorsselaer, \& Viville, 2007). The gel plugs were washed three times with a mixture of $50 \% / 50 \% \mathrm{NH}_{4} \mathrm{HCO}_{3}(25 \mathrm{mM}) /$ acetonitrile. Cysteine residues were reduced with DTT at $57^{\circ} \mathrm{C}$ for $30 \mathrm{~min}$ and alkylated with iodoacetamide at room temperature for 20 min. After dehydration with acetonitrile, proteins were digested in gel with $20 \mu \mathrm{L}$ of 12.5 $\mathrm{ng} / \mu \mathrm{L}$ modified porcine trypsin (Promega, Madison, WI, USA) in $25 \mathrm{mM} \mathrm{NH} \mathrm{NHCO}_{3}$ overnight at room temperature. Then, a double extraction was performed, first with $60 \%(\mathrm{v} / \mathrm{v})$

174 acetonitrile in 5\% (v/v) formic acid and then with $100 \%$ acetonitrile. The resulting tryptic 175 peptides were analyzed using nano liquid chromatography-tandem mass spectroscopy (nano 176 LC-MS/MS). These analyses were performed on an HCT Ultra ion trap (Bruker Daltonics,

177 Bremen, Germany) equipped with a 1100 high-performance liquid chromatography (HPLC) 178 system and a chip cube (Agilent Technologies, Palo Alto, CA, USA) as previously described 179 (Fauquenoy et al., 2008). After loading, the peptide mixture was first concentrated and 180 washed at $4 \mu \mathrm{L} / \mathrm{min}$ in a $40 \mathrm{~nL}$ enrichment column (Agilent Technologies chip), with $0.1 \%$

181 formic acid as an eluent. Chromatographic separation was then carried out on a C18 reverse182 phase capillary column $(75 \mu \mathrm{m} \times 43 \mathrm{~mm}$ in the chip cube) at a flow rate of $300 \mathrm{~nL} / \mathrm{min}$. For 183 tandem MS experiments, automatic switching between MS and MS/MS modes was set as 
184 follows: on each MS spectrum the three most abundant peptides, preferably doubly and triply

185 charged ions, were selected for further isolation and collision-induced dissociation.

186 Mass data acquisitions were monitored by ChemStation (Agilent Technologies),

187 EsquireControl (Bruker Daltonics) and DataAnalysis (Bruker Daltonics) software.

188

189

190

191

192

193

194

\subsubsection{Data interpretation and protein identification}

Mass data collected by nano LC-MS/MS were processed, converted into .mgf peaklist files using DataAnalysis 4.0 (Bruker Daltonics) and interpreted using the Mascot 2.4.3 algorithm (Matrix Science, London, UK) run on a local server. Searches were performed without any molecular weight or isoelectric point restrictions against an in-house generated protein database composed of all vertebrate protein sequences extracted from UniProtKB (Release2014_02, TaxonomyID=7742, 2187035 entries). The database was concatenated in-house using the Mass Spectrometry Data Analysis (MSDA) software suite (Carapito et al., 2014). Known contaminant proteins such as human keratins and porcine trypsin were included in this vertebrate database and therefore only reversed copies of all sequences were added to obtain a target-decoy database of 4,374,070 entries (Elias \& Gygi, 2010). This large database was used because the D. labrax genome is represented by only 2456 protein entries in UniProtKB. Trypsin was selected as the cleavage enzyme and searches were carried out with a mass tolerance of $250 \mathrm{ppm}$ in MS mode and of 0.5 Da in MS/MS mode. A maximum of a single missed cleavage was allowed and some modifications were taken into account: carbamidomethyl (C), acetyl N-terminus of proteins, oxidation (M). Identifications were validated for Mascot Ion scores higher than 45, no decoy hit was identified with this ion score filter; all validated MS/MS spectra were manually checked. 


\subsection{Assessment of the degree of fillet spoilage}

207 Two indicators were studied: BAs (Duflos, Dervin, Malle, \& Bouquelet, 1999) according to 208 the European regulation No. 1441/2007 and TVB-N (Castro, Penedo Padron, Caballero 209 Cansino, Sanjuan Velazquez, \& Millan De Larriva, 2006; Malle \& Poumeyrol, 1989). The 210 samples were analyzed in triplicate at different times after fish slaughter: day $0,3,6,9,13$, 211 and 15.

212 The HPLC method was used for BAs determination in fresh or frozen-thawed fillets.

213 First, $5 \mathrm{~g}$ of flesh were weighed and ground with Ultraturax in $10 \mathrm{~mL}$ of $0.2 \mathrm{M}$ perchloric acid 214 and $100 \mu \mathrm{L}$ of $0.8 \mathrm{mg} / \mathrm{mL} \mathrm{1,3} \mathrm{diaminopropane.} \mathrm{The} \mathrm{homogenized} \mathrm{mixture} \mathrm{was} \mathrm{centrifuged} \mathrm{at}$ $2157000 \times \mathrm{g}$ for $5 \mathrm{~min}$ at $4^{\circ} \mathrm{C}$. In a safe-locked tube, $100 \mu \mathrm{L}$ of supernatant was added to $300 \mu \mathrm{L}$ 216 of saturated sodium carbonate solution and $400 \mu \mathrm{L}$ of $7.5 \mathrm{mg} / \mathrm{mL}$ dansyl chloride. After 217 stirring and incubation at $60^{\circ} \mathrm{C}$ for $5 \mathrm{~min}$ in the dark, samples were cooled under tap water. 218 Then, $100 \mu \mathrm{L}$ of a $100 \mathrm{ng} / \mathrm{mL}$ proline solution was added and, after stirring, the tube was kept $21915 \mathrm{~min}$ in the dark. Afterwards, $500 \mu \mathrm{L}$ of toluene was added and, after stirring, the mixture 220 was stored at $-20^{\circ} \mathrm{C}$ for $30 \mathrm{~min}$. The organic phase was recovered and the remaining phase 221 was evaporated under a stream of nitrogen. The pellet was finally dissolved with $200 \mu \mathrm{L}$ of 222 acetonitrile.

223 Separation was performed using a C18 Kromasil column (5 $\mu \mathrm{m}, 100 \mathrm{~A}, 25 \mathrm{~cm} \times$ 4.6mm). The reversed-phase column was eluted with an acetonitrile gradient. Absorbance was measured at $254 \mathrm{~nm}$. The quantity of BAs was calculated by linear regression against a series of standard 226 solutions $(25,50,100,250 \mathrm{ppm})$.

227 To portray temporal patterns of the BAs and TVB-N content in fresh and frozen-thawed 228 fillets, the cumulated function method was used (Ibanez, Fromentin, \& Castel, 1993). The 229 calculation consists in subtracting a reference value (here, the mean of the series) from the 230 date, and then successively adding the residuals, forming a cumulative function. Successive 
231

232

233

234

235

236

237

238

239

240

negative residuals produce a decreasing slope indicating values lower than the overall mean, whereas successive positive residuals create an increasing slope indicating higher values than the overall mean. Values that are only slightly different from the mean show no slope.

\section{Results}

3.1. 2D-electrophoresis comparison of fresh and frozen-thawed fillets

In a preliminary study to identify potential biochemical markers, 2D-electrophoresis (2-DE) was used to compare protein maps of fresh versus frozen-thawed European sea bass fillet exudates. Experiments were performed on 3-day-old fillets. Two representative 2-DE maps are shown in Fig. 1. Both show numerous spots, mainly distributed in the basic part of the $\mathrm{pH}$ gradient, but their patterns clearly differed. The 2-DE profiles of frozen-thawed exudates showed more spots than the fresh profiles. Focusing in particular on protein spots with low isoelectric values and low molecular weights (Fig. 1), the 2D-E profiles of the frozen-thawed fillets are distinctive with respect to two spots - hereafter called 1 and $2-$, which were absent in the fresh fillet gel profiles. To confirm that these differences appeared regardless of the degree of spoilage, time-course analyses were carried out.

\subsection{2-DE time-course profiles of exudates}

\subsubsection{2-DE time-course profiles of fresh fillet exudates}

From slaughtering day (day 0 ) to day 15 , analyses were performed in triplicate. 2D-E on the fresh fillet exudates showed that from day 0 to day 9 , there were no spots located in the area of interest of the protein profiles (Fig. 2). Only a faint spot (noted 2) appeared on day 15 in the fresh fillet profile (Fig. 2A).

\subsubsection{2-DE time-course profiles of frozen-thawed fillet exudates}


253 In contrast to the profiles of fresh fillet exudates, the frozen-thawed fillet 2-DE profiles 254 clearly showed two spots (1 and 2) as of day 0 . The intensity of the two spots gradually 255 increased over time (Fig. 2B).

\subsection{Time course of spoilage indicators}

257 To distinguish spoiled fillets from thawed fillets and to check that the potential markers 258 revealed by 2-DE could not also be considered as indicators of spoilage, freshness was 259 evaluated using normalized methods. Therefore, BAs and TVB-N levels were determined on 260 each day of the experiment (Fig. 3).

\subsubsection{Fresh fillet analysis}

262 Changes in BAs rates and in TVB-N content of fresh fillets are given in Fig. 3A. All values 263 increased slightly or remained similar, never exceeding $10 \mathrm{ppm}$ for BAs or $25 \mathrm{mg} / 100 \mathrm{~g}$ for 264 TVB-N until day 9. After this period, levels increased significantly. Histamine and putrescine 265 never exceeded the upper legal limit, although TVB-N and cadaverine showed increases that 266 exceeded American limits (respectively, $25 \mathrm{mg} / 100 \mathrm{~g}$ and $50 \mathrm{mg} / \mathrm{kg}$ ) and European limits 267 (100 mg/kg). Examination of the related cumulated sums (Fig. 3B) highlighted two distinct

268 periods: from day 0 to day 9, and after day 9. In the second period (day 13 and day 15), two 269 markers (cadaverine and TVB-N) indicated that the fish quality was not acceptable according 270 to US and European regulations. As shown in Fig. 3A regarding fresh fillets, from day 9 after 271 slaughter, there was significant increase in histamine and cadaverine. Between day 9 and day 272 13, histamine, cadaverine and putrescine markedly increased, reaching very high levels on 273 day 13. The same phenomenon was observed for TVB-N (data not shown).

\subsubsection{Frozen-thawed fillet analysis}

275 Changes in BAs concentrations and TVB-N were different for the frozen-thawed fillets (Fig. 276 3C). Only putrescine concentrations showed change, quite similar to the one observed for the 
277 fresh fillets. The samples, that had been stored in ice for zero to six days before freezing, then

278 thawed, showed very few changes in their BAs levels, close to zero, whereas the TVB-N

279 levels were relatively stable at approximately $22 \mathrm{mg} / 100 \mathrm{~g}$. Then, as of day 9 , cadaverine and

280 TVB-N levels exceeded the upper legal limit. Cadaverine and histamine levels were 281 approximately 2.4 and 10 times higher at the end of the experiments, exceeding $200 \mathrm{mg} / \mathrm{kg}$. 282 The related cumulated sums revealed two different periods, depending on the indicator (Fig. 283 3D). The periods during which histamine was observed in the frozen-thawed fillets were 284 identical to the ones observed in fresh fillets. For the other indicators (cadaverine, putrescine and TVB-N), the first period (D0 to D6) was shorter than for the fresh samples. This means that by considering the indicators that exceeded the legal limits (cadaverine and TVB-N), 287 thawed fillets became unfit for human consumption sooner (as of day 9) than fresh fillets.

288 These results confirm that freezing and thawing facilitate development of microflora (data not shown) and promote spoilage of fish.

\subsection{Protein identification}

291 Priority was given to characterizing proteins located in the area of interest, corresponding to an isoelectric point between 3 and 4 and molecular weights comprised between 10 and 12 $\mathrm{kDa}$. The 2-DE gels of frozen-thawed fish were repeated $(\mathrm{n}=10)$ to collect a sufficient amount

294 of spots 1 and 2 to ensure the reproducibility of their content (Fig. 2).

295 Nano LC-MS/MS analyses provided unambiguous identification of parvalbumin isoforms in 296 all samples of spots 1 and 2 as summarized in Table 1.

297 Although the genome of D. labrax has been sequenced 298 (http://genomesonline.org/project?id=8120), its annotation is not complete and only 2456 299 proteins are present in the UniProtKB database (2375 protein entries are recorded in the 300 NCBInr database). Therefore, a large database including all vertebrate protein entries was 301 used to allow for cross-species protein identifications. Thus, two groups of parvalbumin 
302 isoforms were identified in spots 1 and 2 based on three unique peptides. Peptides

303 LFLQNFSAGAR and SGFIEEDELK unambiguously matched 16 parvalbumin proteins 304 recorded for the following species in UniProtKB: Cyprinus carpio, Boreogadus saida, 305 Siniperca chuatsi, Hypomesus transpacificus, Thunnus albacares, Danio rerio, Carassius 306 auratus, Macruronus magellanicus, Macruronus novaezelandiae, Fundulus heteroclitus, 307 Fundulus grandis, Ictalurus punctatus. Peptides AFAIIDQDK and SGFIEEDELK 308 unambiguously matched 14 parvalbumin proteins recorded for the following taxa in

309 UniProtKB: Cyprinus carpio, Micropterus salmoides, Gillichthys mirabilis, Gillichthys seta,

310 Siniperca chuatsi, Ictalurus furcatus, Hypophthalmichthys nobilis, Hypophthalmichthys

311 molitrix, Kryptolebias marmoratus, Xiphias gladius, Ictalurus punctatus.

312 A representative MS/MS spectrum of each identified peptide is provided in Fig. 4.

313 Here, 431 out of 886 parvalbumins present in the database belong to bony fish species and all 314 species with matching peptides in this study belong to this category.

315 Two parvalbumins had been previously identified by proteomic profiling of sea bass muscle 316 using 2-DE (Terova, Pisanu, Roggio, Preziosa, Saroglia, \& Addis, 2014). In addition, 317 parvalbumins are proteins with low molecular weight (10 to $12.5 \mathrm{kDa}$ ) and an acidic 318 isoelectric point (4.1 to 5.2), correlating with the region in which the spots were found on the 319 2-DE gels.

\section{Discussion}

321 To differentiate a fresh sea bass fillet from a frozen-thawed one, exudates were studied, the 322 supernatant present after fillets have been centrifuged. The 2-DE patterns from these exudates revealed areas of differentiation between fresh and frozen-thawed fish. This study focused only on the protein composition of the exudates, which contains soluble proteins that may be released after freezing and thawing (Martinez \& Friis, 2004; Terova, Pisanu, Roggio,

326 Preziosa, Saroglia, \& Addis, 2014). Instead of studying the total proteome, this approach 
concentrated on a limited number of proteins that can be used to characterize easily the differences between fresh and frozen-thawed fillets. Results indicated that proteins of low molecular weight and low acid isoelectric values showed the most significant differentiation. Repeated 2-DE gels of exudates from frozen-thawed fish fillet revealed the same two differentiating spots compared with 2-DE of exudates from fresh fish fillets. These two spots appear in fresh fish fillet 2-DE profiles only 13 days after slaughter and beyond. To check the degree of spoilage of sea bass fillets, the time course of spoilage indicators such as BAs and TVB-N were also studied to ensure that the observed proteins did not correspond to proteins normally produced during post-mortem storage as described in previous 2-DE studies (Terova et al., 2011; Terova, Pisanu, Roggio, Preziosa, Saroglia, \& Addis, 2014; Verrez-Bagnis, Ladrat, Morzel, Noël, \& Fleurence, 2001).

BAs and TVB-N content show spoilage for fresh fillets and for frozen-thawed fillets from day 9 as revealed by related cumulated sums. After nine days, fresh or frozen-thawed fillets show spoilage beyond the legal limits of consumption. Nevertheless, the 2-DE analyses could differentiate between fresh and frozen-thawed fish fillets up until day 13. The 2-DE method is therefore valuable for testing fish fillets up until their use-by date.

The two spots of interest identified in the 2-DE from frozen-thawed fillet were characterized by MS/MS as parvalbumin isoforms. Parvalbumins, which are sarcoplasmic proteins, were found in the frozen-thawed fillet exudates because membranes rupture following the formation of ice crystals inside cells during freezing (Morel, 1979; Tironi, De Lamballerie, \& Le-Bail, 2010). These proteins are known as the main fish allergens (Swoboda et al., 2002; Van Do, Hordvik, Endresen, \& Elsayed, 2005). Parvalbumin shares similarities in numerous species, possibly indicating that this protein is ubiquitous (Chen, Hefle, Taylor, Swoboda, \& Goodman, 2006). 
351

352

353

354

355

356

357

Fish parvalbumins are already used as markers to detect fish derivatives in final food products (Faeste \& Plassen, 2008), to differentiate commercial hake varieties (Carrera, García-López, Martín del Río, Martínez-Rodríguez, Solé, \& Mancera, 2007) and to identify different fish species (Rehbein, Kundiger, Pineiro, \& Perez-Martin, 2000).

\section{Conclusion}

The present study provides a 2-DE comparative analysis of the exudates to differentiate frozen-thawed sea bass fillets from fresh sea bass fillets. Membrane disruption after freezing leads to protein release and thus their presence in exudates. LC-MS/MS analysis identified two protein spots as parvalbumin isoforms, and these were specifically recovered in frozenthawed fillets of sea bass at each day of analysis from the beginning of the study. These same spots were not observed in fresh fillets until at least 13 days of storage between 0 and $4^{\circ} \mathrm{C}$. These two proteins could not be mistaken with spoilage indicators since the fillets were considered as unfit for the human consumption earlier in the time course analysis of biogenic amines and TVB-N. This study demonstrated that 2-DE is a relevant tool to differentiate skinless fresh fillets from frozen-thawed ones. It was therefore suggested that parvalbumin could be used as a marker to differentiate fresh from frozen-thawed sea bass fillets and should be investigated in other fish species of high commercial value. This work opens the way for future studies to develop a rapid and accurate test and to ultimately provide it to producers and official authorities.

\section{Acknowledgements}

This work was funded by the Nord-Pas de Calais regional council. The authors wish to thank Dorothée Vincent for her advice on statistical analyses and Emmanuelle Croquelois-Clément for her technical assistance. Sylvain Marlard is grateful to the Nord-Pas de Calais regional council for its financial support of his $\mathrm{PhD}$ studies. 


\section{References}

376

377

378

379

380

381

382

383

384

385

386

387

388

389

390

391

392

393

394

395

396

397

398

399

400

401

402

403

404

405

406

407

408

409

410

411

412

413

414

415

416

417

418

419

420

421

422

Ayala, M. D., López Albors, O., Blanco, A., García Alcázar, A., Abellán, E., Ramírez Zarzosa, G., \& Gil, F. (2005). Structural and ultrastructural changes on muscle tissue of sea bass, Dicentrarchus labrax L., after cooking and freezing. Aqualculture, 250(12), 215-231.

Baron, C. P., Kjaersgard, I. V., Jessen, F., \& Jacobsen, C. (2007). Protein and lipid oxidation during frozen storage of rainbow trout (Oncorhynchus mykiss). J Agric Food Chem, 55(20), 8118-8125.

Benjakul, S., \& Bauer, F. (2001). Biochemical and physicochemical changes in catfish (Silurus glanis Linne) muscle as influenced by different freeze-thaw cycles. Food Chemistry, 72(2), 207-217.

Berrini, A., Tepedino, V., Borromeo, V., \& Secchi, C. (2006). Identification of freshwater fish commercially labelled "perch" by isoelectric focusing and two-dimensional electrophoresis. Food Chemistry, 96(1), 163-168.

Bradford, M. (1976). A rapid and sensitive method for the quantitation of microgram quantities of protein utilising the principle of protein-dye binding. Anal. Biochem., 72, 248-254.

Buhr, N., Carapito, C., Schaeffer, C., Hovasse, A., Van Dorsselaer, A., \& Viville, S. (2007). Proteome analysis of the culture environment supporting undifferentiated mouse embryonic stem and germ cell growth. Electrophoresis, 28(10), 1615-1623.

Carapito, C., Burel, A., Guterl, P., Walter, A., Varrier, F., Bertile, F., \& Van Dorsselaer, A. (2014). MSDA, a proteomics software suite for in-depth Mass Spectrometry Data Analysis using grid computing. PROTEOMICS, 14(9), 1014-1019.

Carrera, E. P., García-López, A., Martín del Río, M. d. P., Martínez-Rodríguez, G., Solé, M., \& Mancera, J. M. (2007). Effects of 17[beta]-estradiol and 4-nonylphenol on osmoregulation and hepatic enzymes in gilthead sea bream (Sparus auratus). Comparative Biochemistry and Physiology Part C: Toxicology \& Pharmacology, 145(2), 210-217.

Castro, P., Penedo Padron, J. C., Caballero Cansino, M. J., Sanjuan Velazquez, E., \& Millan De Larriva, R. (2006). Total volatile base nitrogen and its use to assess freshness in European sea bass stored in ice. Food Control, 17(4), 245-248.

Chen, L., Hefle, S. L., Taylor, S. L., Swoboda, I., \& Goodman, R. E. (2006). Detecting fish parvalbumin with commercial mouse monoclonal anti-frog parvalbumin IgG. J Agric Food Chem, 54(15), 5577-5582.

Duflos, G., Dervin, C., Malle, P., \& Bouquelet, S. (1999). Use of biogenic amines to evaluate spoilage in plaice (Pleuronectes platessa) and whiting (Merlangus merlangus). Journal of AOAC International, 82(6), 1357-1363.

Duflos, G., Le Fur, B. L., Mulak, V., Becel, P., \& Malle, P. (2002). Comparison of methods of differentiating between fresh and frozen-thawed fish or fillets. Journal of the Science of Food and Agriculture, 82(12), 1341-1345.

Duun, A. S., \& Rustad, T. (2007). Quality changes during superchilled storage of cod (Gadus morhua) fillets. Food Chemistry, 105(3), 1067-1075.

Elias, J. E., \& Gygi, S. P. (2010). Target-decoy search strategy for mass spectrometry-based proteomics. Methods Mol Biol, 604, 55-71.

Etienne, M., Jerôme, M., Fleurence, J., Rehbein, H., Kündiger, R., Mendes, R., Costa, H., \& Martinez, I. (2001). Species identification of formed fishery products and high pressure-treated fish by electrophoresis: a collaborative study. Food Chemistry, 72(1), 105-112. 
Faeste, C. K., \& Plassen, C. (2008). Quantitative sandwich ELISA for the determination of fish in foods. J Immunol Methods, 329(1-2), 45-55.

Fauquenoy, S., Morelle, W., Hovasse, A., Bednarczyk, A., Slomianny, C., Schaeffer, C., Van Dorsselaer, A., \& Tomavo, S. (2008). Proteomics and Glycomics Analyses of NGlycosylated Structures Involved in Toxoplasma gondii-Host Cell Interactions. Molecular \& Cellular Proteomics, 7(5), 891-910.

Hochstrasser, D. F., Harrington, M. G., Hochstrasser, A. C., Miller, M. J., \& Merril, C. R. (1988). Methods for increasing the resolution of two-dimensional protein electrophoresis. Analytical Biochemistry, 173(2), 424-435.

Hochstrasser, D. F., Patchornik, A., \& Merril, C. R. (1988). Development of polyacrylamide gels that improve the separation of proteins and their detection by silver staining. Analytical Biochemistry, 173(2), 412-423.

Ibanez, F., Fromentin, J.-M., \& Castel, J. (1993). Application de la méthode des sommes cumulées à l'analyse des séries chronologiques en océanographie (Vol. 316). Paris, France: Elsevier.

Karoui, R., Thomas, E., \& Dufour, E. (2006). Utilisation of a rapid technique based on frontface fluorescence spectroscopy for differentiating between fresh and frozen-thawed fish fillets. Food Research International, 39(3), 349-355.

Kjaersgard, I. V. H., Norrelykke, M. R., \& Jessen, F. (2006). Changes in cod muscle proteins during frozen storage revealed by proteome analysis and multivariate data analysis. PROTEOMICS, 6(5), 1606-1618.

Malle, P., \& Poumeyrol, M. (1989). A New Chemical Criterion for the Quality Control of Fish: Trimethylamine/Total Volatile Basic Nitrogen (\%). Journal of Food Protection, 52(6), 419-423.

Martinez, I., \& Friis, T. J. (2004). Application of proteome analysis to seafood authentication. PROTEOMICS, 4(2), 347-354.

Martinez, I., Slizyte, R., \& Dauksas, E. (2007). High resolution two-dimensional electrophoresis as a tool to differentiate wild from farmed cod (Gadus morhua) and to assess the protein composition of klipfish. Food Chemistry EFFoST 2005 Annual Meeting: Innovations in traditional foods, 102(2), 504-510.

Martino, M. N., Otero, L., Sanz, P. D., \& Zaritzky, N. E. (1998). Size and location of ice crystals in pork frozen by high-pressure-assisted freezing as compared to classical methods. Meat Science, 50(3), 303-313.

Matsumoto, J. (1979). Denaturation of fish muscle proteins during frozen storage. In A. i. c. series (Ed.), Proteins at low temperatures O. Fennema ed. ed., vol. 180): Washington, D.C.

Mazur, P. (2010). A biologist's view of the relevance of thermodynamics and physical chemistry to cryobiology. Cryobiology, 60(1), 4-10.

Morel, M. (1979). Une méthode pour déterminer si le poisson est à l'état frais ou décongelé. Science et Pêche, Bull. Inst. Pêches marit., $n^{\circ} 288,13-17$.

Pegg, D. E. (2010). The relevance of ice crystal formation for the cryopreservation of tissues and organs. Cryobiology, 60(3 Suppl), S36-44.

Rehbein, H., Kundiger, R., Pineiro, C., \& Perez-Martin, R. I. (2000). Fish muscle parvalbumins as marker proteins for native and urea isoelectric focusing. Electrophoresis, 21(8), 1458-1463.

Swoboda, I., Bugajska-Schretter, A., Verdino, P., Keller, W., Sperr, W. R., Valent, P., Valenta, R., \& Spitzauer, S. (2002). Recombinant carp parvalbumin, the major crossreactive fish allergen: a tool for diagnosis and therapy of fish allergy. J Immunol, 168(9), 4576-4584. 
Tchir, J., \& Acker, J. P. (2010). Mitochondria and membrane cryoinjury in micropatterned cells: effects of cell-cell interactions. Cryobiology, 61(1), 100-107.

Terova, G., Addis, M. F., Preziosa, E., Pisanu, S., Pagnozzi, D., Biosa, G., Gornati, R., Bernardini, G., Roggio, T., \& Saroglia, M. (2011). Effects of postmortem storage temperature on sea bass (Dicentrarchus labrax) muscle protein degradation: Analysis by 2-D DIGE and MS. PROTEOMICS, 11(14), 2901-2910.

Terova, G., Pisanu, S., Roggio, T., Preziosa, E., Saroglia, M., \& Addis, M. F. (2014). Proteomic profiling of sea bass muscle by two-dimensional gel electrophoresis and tandem mass spectrometry. Fish Physiology and Biochemistry, 40(1), 311-322.

Tironi, V., De Lamballerie, M., \& Le-Bail, A. (2010). Quality changes during the frozen storage of sea bass (Dicentrarchus labrax) muscle after pressure shift freezing and pressure assisted thawing. Innovative Food Science and Emerging Technologies, 11(4), 565-573.

Tironi, V., LeBail, A., \& De Lamballerie, M. (2007). Effects of Pressure-Shift Freezing and Pressure-Assisted Thawing on Sea Bass (Dicentrarchus labrax) Quality. Journal of Food Science, 72(7), C381-C387.

Van Do, T., Hordvik, I., Endresen, C., \& Elsayed, S. (2005). Characterization of parvalbumin, the major allergen in Alaska pollack, and comparison with codfish Allergen M. Molecular Immunology, 42(3), 345-353.

Verrez-Bagnis, V., Ladrat, C., Morzel, M., Noël, J., \& Fleurence, J. (2001). Protein changes in post mortem sea bass (Dicentrarchus labrax) muscle monitored by one- and twodimensional gel electrophoresis. Electrophoresis, 22(8), 1539-1544.

Zhu, S., Ramaswamy, H. S., \& Simpson, B. K. (2004). Effect of high-pressure versus conventional thawing on color, drip loss and texture of Atlantic salmon frozen by different methods. LWT - Food Science and Technology, 37(3), 291-299. 
500 Fig. 1. Overlay of 2D gel electrophoresis profiles. A: exudates of fresh sea bass fillets stored 501 on ice for 3 days (D3). B: exudate of 3-day-old (D3) frozen-thawed sea bass fillet. 12.5\% 502 polyacrylamide gels were used with isoelectric points from 3 to 10 and stained with silver 503 nitrate. The triangle is a mark and the box indicates the area of interest in which the two 504 studied spots referred to as 1 and 2 appear. MW: Molecular Weight

505 Fig. 2. Changes in the area of interest (bottom left-hand part of the 2-DE gels). A: exudates of 506 fresh sea bass fillets (D0) stored on ice for 3, 6, 9, 13 or 15 days before analysis. B: exudates 507 of frozen-thawed sea bass fillets. Fillets were stored on ice for 0, 3 and 6 days, then frozen for 508 less than 15 days and thawed on ice $24 \mathrm{~h}$ before analysis.

509 Fig. 3. Changes in biogenic amines and total volatile basic nitrogen levels in fresh (A) and 510 frozen-thawed (C) fillets and cumulative sums in fresh (B) and frozen-thawed (D) sea bass 511 fillets.

512 Analyses were performed in triplicate at different time periods after fish slaughter: day 0, 3, 6, $5139,13,15$

514 A. Changes in biogenic amine levels and in the TVB-N content of fresh fillets

515 B. Plot of the related cumulated sums (Cum. sum.) in fresh fillets

516 C. Changes in biogenic amine levels and in the TVB-N content of frozen-thawed fillets

517 D. Plot of the related cumulated sums (Cum. sum.) in frozen-thawed fillets

518 Storage period indicated in days corresponds to:

519 - the analysis day $(0,3,6,9,12$ or 15) after fish slaughter for fresh fillets stored at 0 to $520+4^{\circ} \mathrm{C}(\mathrm{A}, \mathrm{B})$ 
- the analysis day after storage on ice for $0,3,6,9,12$ or 15 days followed by a freezing step at $-30^{\circ} \mathrm{C}$ and storage at $-20^{\circ} \mathrm{C}$ for less than 15 days before thawing for $24 \mathrm{~h}$ at between 0 and $+4^{\circ} \mathrm{C}$ for the frozen-thawed fillets $(\mathrm{C}, \mathrm{D})$

524 Fig. 4. MS/MS spectra allowing the identification of parvalbumin isoforms

525 A. Representative MS/MS spectrum of the SGFIEEDELK peptide

526 B. Representative MS/MS spectrum of the LFLQNFSAGAR peptide

527 C. Representative MS/MS spectrum of the AFAIIDQDK peptide

\section{Table 1}

529 Identification of sea bass protein spots based on LC-MS/MS analysis and cross-species

530 matching with database sequences 


\begin{tabular}{cccccc}
\hline Spot & Protein name & $\begin{array}{c}\text { Protein } \\
\text { accession } \\
\text { numbers }\end{array}$ & $\begin{array}{c}\text { Protein molecular } \\
\text { weight (Da) }\end{array}$ & $\begin{array}{c}\text { Number } \\
\text { of unique } \\
\text { peptides }\end{array}$ & $\begin{array}{c}\text { Peptide } \\
\text { sequences }\end{array}$ \\
\hline Spot 1 & $\begin{array}{c}\text { Parvalbumin alpha } \\
\text { (Cyprinus carpio) }^{\mathrm{a}}\end{array}$ & P09227 & 11444 & 2 & $\begin{array}{c}\text { LFLQNFSAGAR - } \\
\text { SGFIEEDELK }\end{array}$ \\
\cline { 2 - 6 } & $\begin{array}{c}\text { Parvalbumin beta-2 } \\
\text { (Cyprinus carpio) }^{\mathrm{b}}\end{array}$ & P02618 & 11429 & 2 & $\begin{array}{c}\text { AFAIIDQDK - } \\
\text { SGFIEEDELK }\end{array}$ \\
\hline Spot 2 & $\begin{array}{c}\text { Parvalbumin alpha } \\
\text { (Cyprinus carpio) }^{\mathrm{a}}\end{array}$ & P09227 & 11444 & 2 & $\begin{array}{c}\text { LFLQNFSAGAR - } \\
\text { SGFIEEDELK }\end{array}$ \\
\hline & $\begin{array}{c}\text { Parvalbumin beta-2 } \\
\text { (Cyprinus carpio) }^{\mathrm{b}}\end{array}$ & P02618 & 11429 & 2 & $\begin{array}{c}\text { AFAIIDQDK - } \\
\text { SGFIEEDELK }\end{array}$ \\
\hline
\end{tabular}

${ }^{\mathrm{a}}$ and ${ }^{\mathrm{b}}$ : Lists of proteins identified with identical set of peptides:

${ }^{a}$ Parvalbumin (Boreogadus saida) tr|C0LEL4; Parvalbumin beta-1 (Cyprinus carpio) tr|E0WD92; Parvalbumin 4 (Siniperca chuatsi) tr|D2KQG3; Parvalbumin (Fragment) (Hypomesus transpacificus) tr|C3UVG3; Parvalbumin (Thunnus albacares) tr|C6GKU3; Parvalbumin 3 (Danio rerio) tr|Q7ZT36; Parvalbumin 1 (Carassius auratus) tr|G8GWA2; Parvalbumin (Cyprinus carpio) tr|Q8UUS3; Parvalbumin-2 (Danio rerio) sp|Q9I8V0; Parvalbumin (Siniperca chuatsi) tr|B9VJM3; Parvalbumin beta 3 (Fragments) (Macruronus magellanicus) splP86740; Parvalbumin beta 3 (Fragments) (Macruronus novaezelandiae) sp|P86742; Parvalbumin (Fundulus heteroclitus) tr|C0LEL6; Parvalbumin (Fundulus grandis) tr|C0LEL8; Parvalbumin-2 (Ictalurus punctatus) tr|E3TGD0

b Parvalbumin (Micropterus salmoides) tr|C0LEL5; Parvalbumin beta-2 (Cyprinus carpio) tr|E0WD93; Parvalbumin 1 (Fragment) (Gillichthys mirabilis) tr|C1J0K6; Parvalbumin 1 (Fragment) (Gillichthys seta) tr|C1J0K7; Parvalbumin 2 (Siniperca chuatsi) tr|D2KQG1; Parvalbumin beta (Ictalurus furcatus) tr|E3TBW7; Parvalbumin (Hypophthalmichthys nobilis) tr|B5TTU7; Parvalbumin (Hypophthalmichthys molitrix) tr|B6UV98; Parvalbumin 1 (Kryptolebias marmoratus) tr|Q6B4H8; Parvalbumin (Cyprinus carpio) tr|Q8UUS2; Betaparvalbumin (Xiphias gladius) tr|B9W4C2; Parvalbumin 4 (Hypophthalmichthys molitrix) tr|R9R015; Parvalbumin (Fragment) (Ictalurus punctatus) tr|Q804Z0 
A


B

$\mathrm{pH} 3$



$\mathrm{pH} 10$

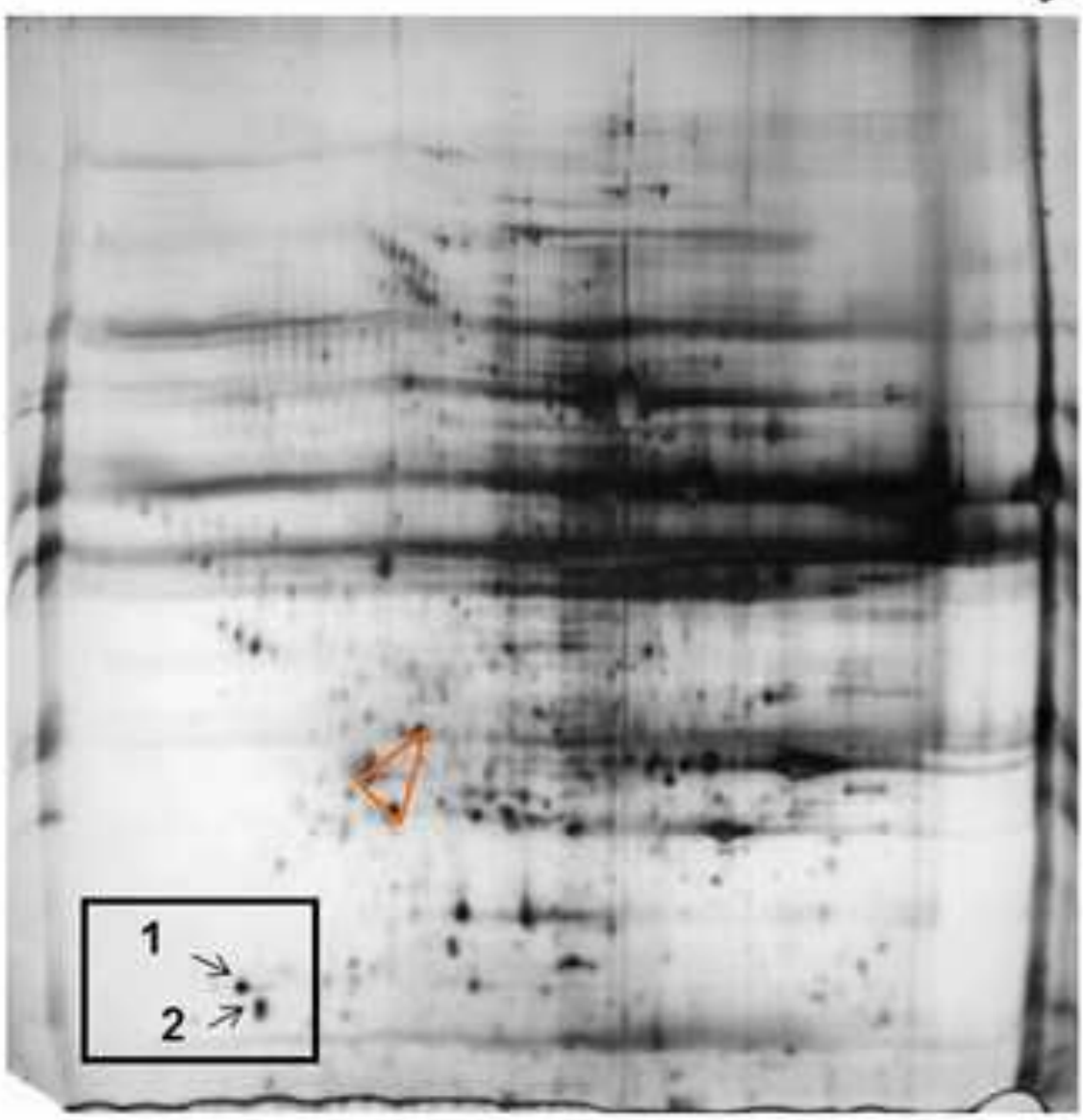


Published in Food Chemistry and available online at https://doi.org/10.1016/j.foodchem.2014.12.065
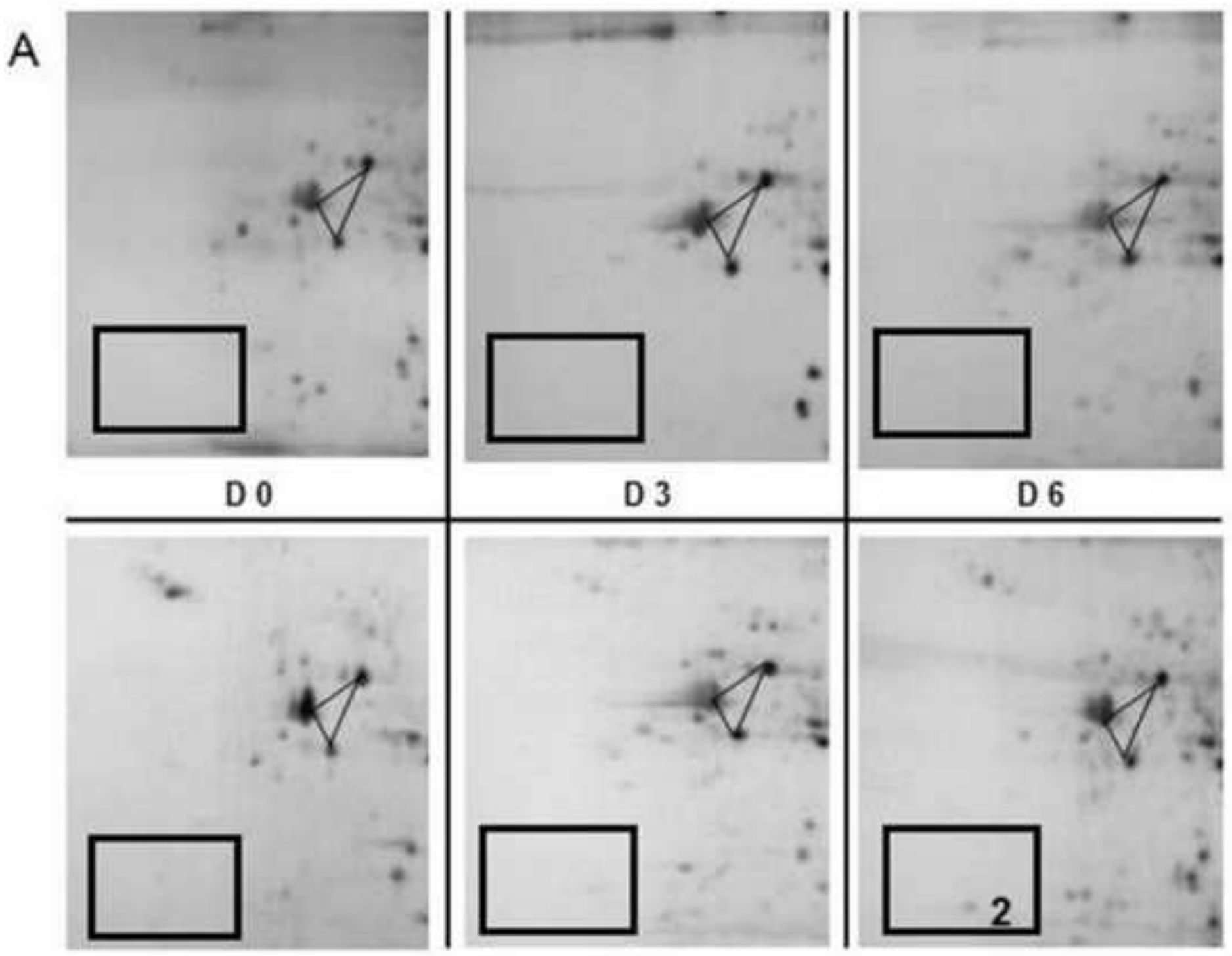

D 9

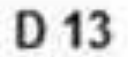

D 15

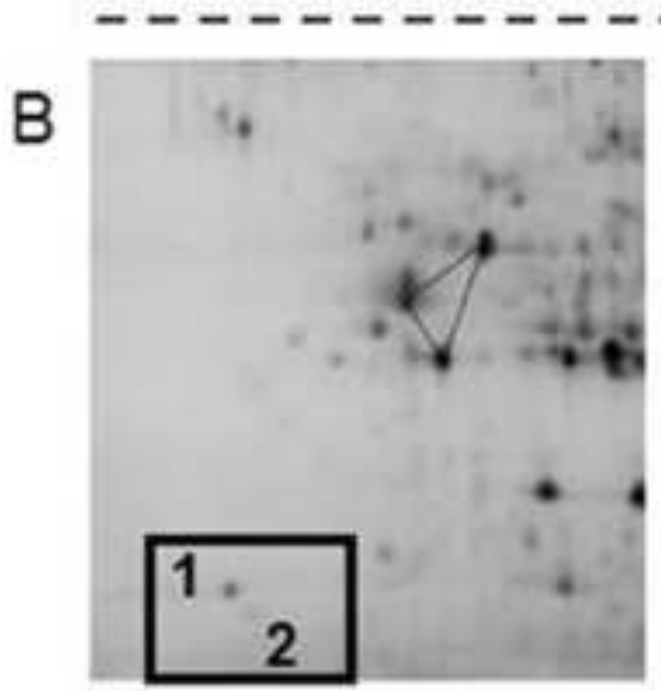

D 0
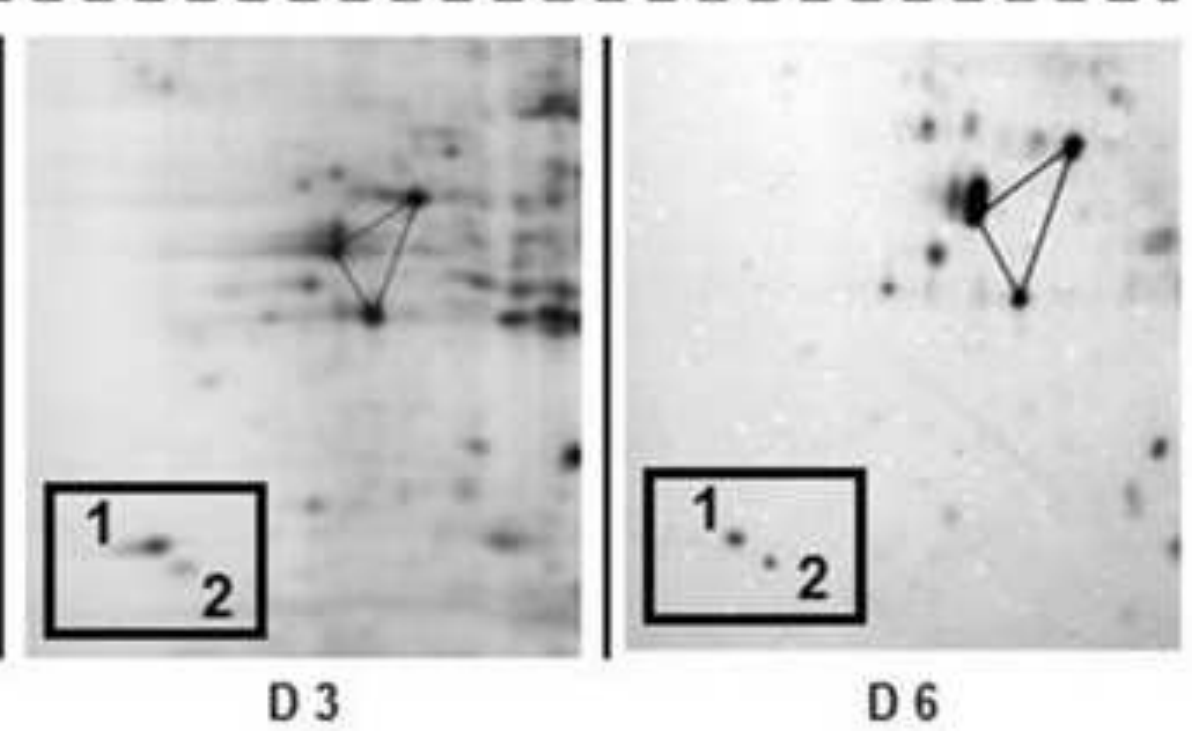

D 3
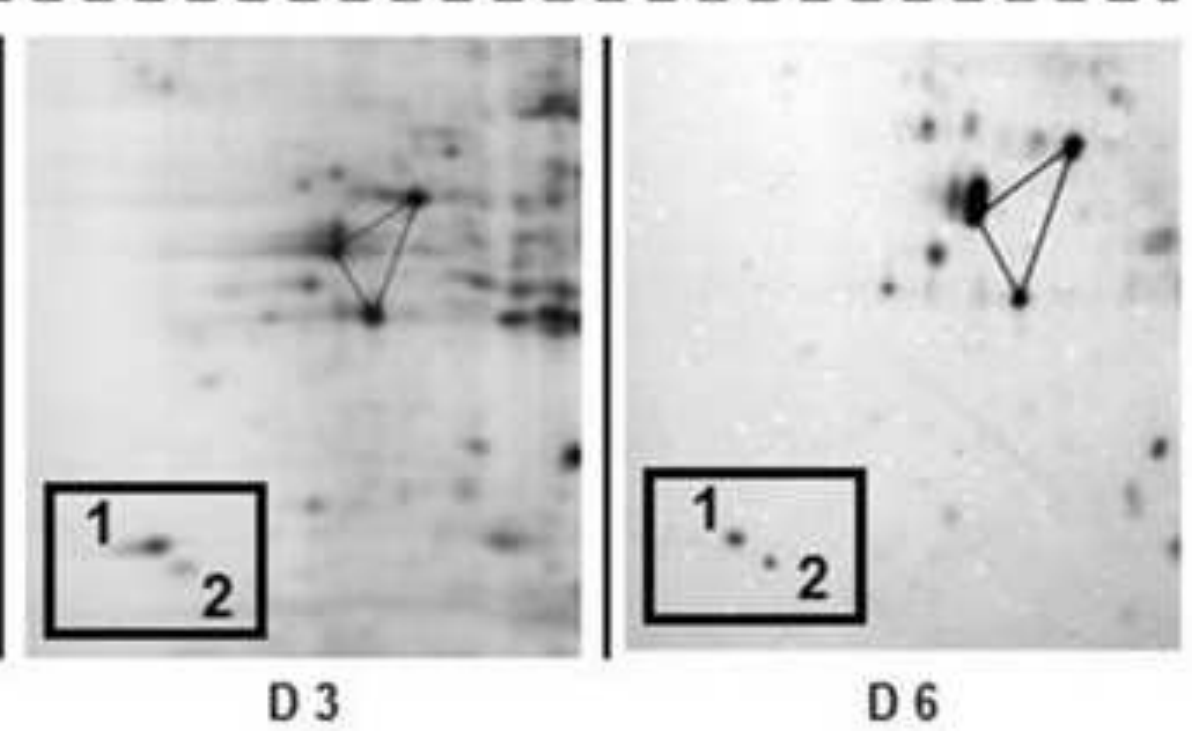

D 6 
A



B

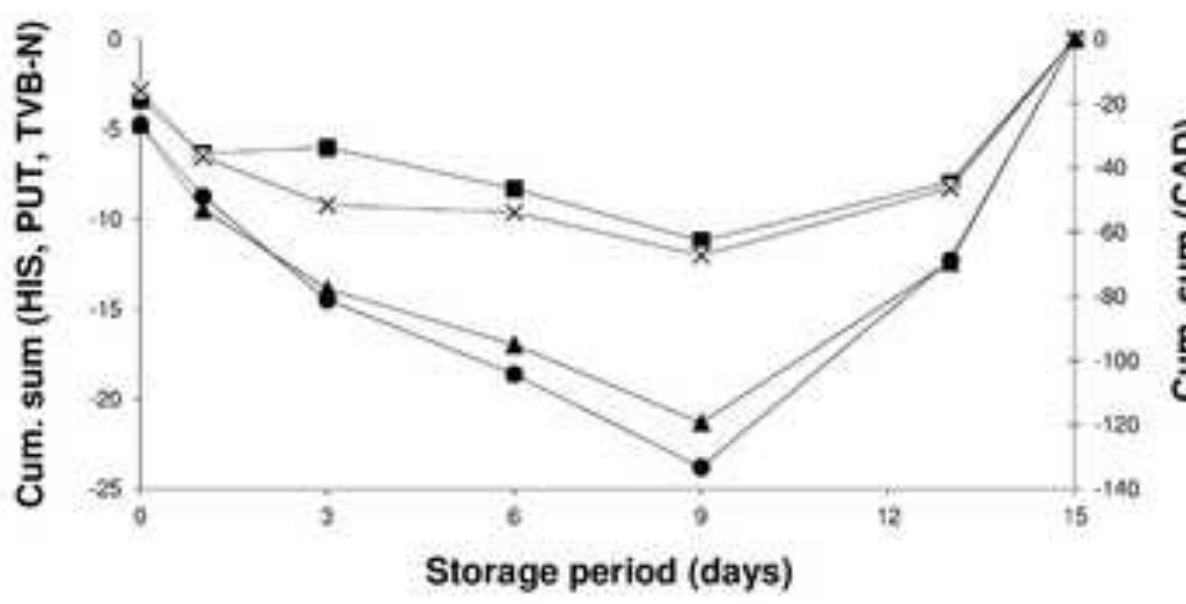

c


蛋 

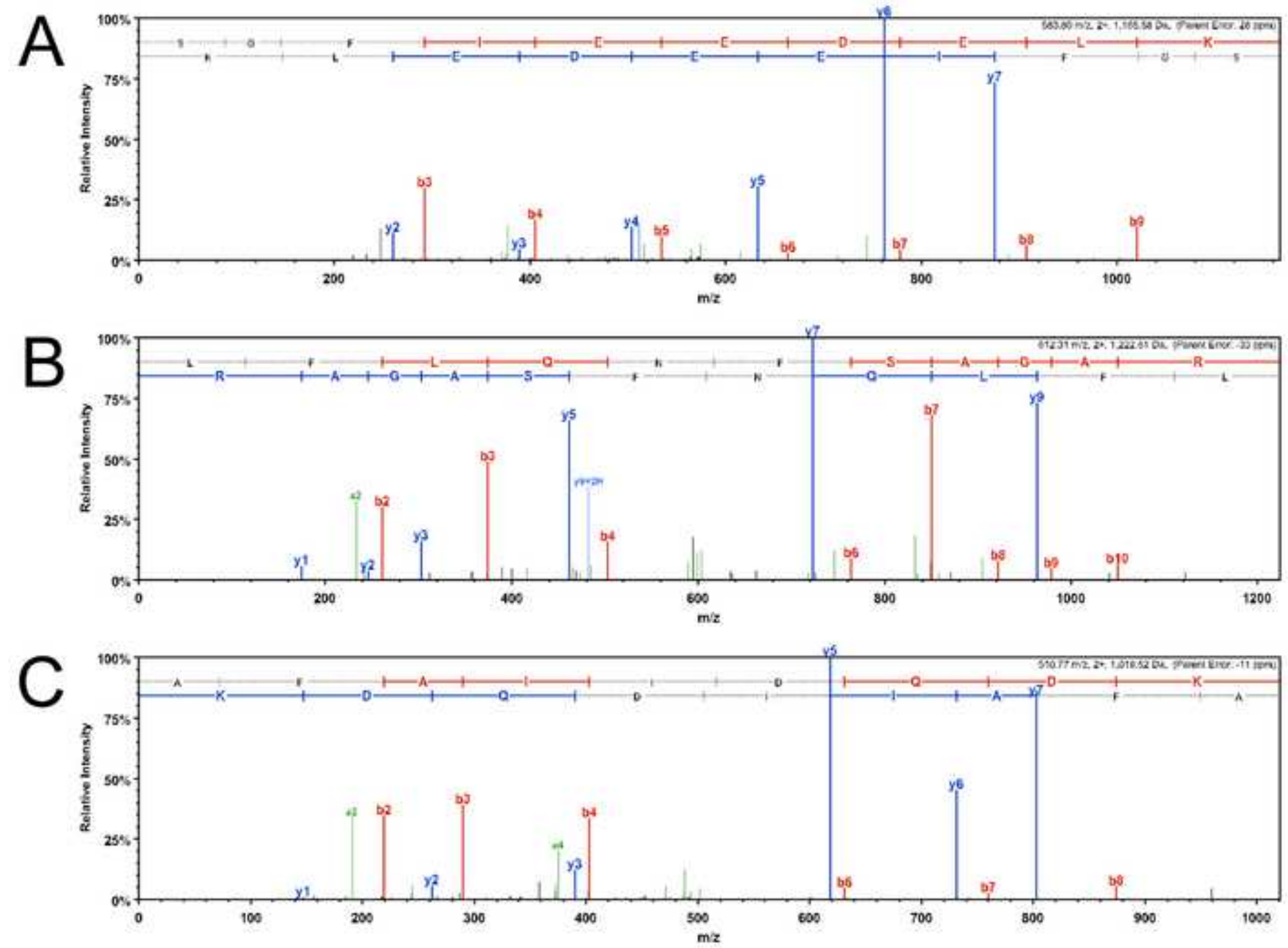